\title{
PEMBERDAYAAN MASYARAKAT : KAMPUNG TUNAGRAHITA MENUJU KAMPUNG MANDIRI DESA KARANGPATIHAN, PONOROGO, INDONESIA
}

\author{
Yeni Rosilawati ${ }^{1}$, Dinar Ayu Amalia ${ }^{2}$, Aswad Ishak ${ }^{3}$ \\ 1yenirosilawati@gmail.com, ${ }^{2}$ Dinar.ayuamalia48@gmail.com ${ }_{2}^{3}$ ishak@umy.ac.id \\ Program Studi Ilmu Komunikasi, Universitas Muhammadiyah Yogyakarta
}

\begin{tabular}{l} 
Article Info \\
\hline $\begin{array}{l}\text { community development, men- } \\
\text { toring, intellectual disability, inde- } \\
\text { pendent, creative }\end{array}$
\end{tabular}

pendent, creative

\begin{abstract}
People with intellectual disabilities in Indonesia are vulnerable to discrimination due to lack of information on diseases, treatment, education, public access, and very limited job opportunities. Karangpatihan is a village called Kampung Tunagrahita (Mental Retardation Village) because 86 of its people are suffering from an intellectual disability. A community development program of self-help group (SHG) named Rumah Harapan Karangpatihan Bangkit aims to improve the social and economic capabilities of people with intellectual disabilities in Karangpatihan Village, Ponorogo, Indonesia. The researcher applied a qualitative method in the form of a case study. Data collection techniques used in this study were an in-depth interview with the Head of Karangpatihan Village, managers of Rumah Harapan Karangpatihan Bangkit, and people with intellectual disabilities involved within the program. Secondary data were obtained through the report of the SHG Rumah Harapan Karangpatihan Bangkit and mass media news clipping. This research shows that community development programs are carried out through mentoring mentally retarded citizens through counseling individually and in groups using sign language. Through effective mentoring, mentally disabled people in Karangpatihan Village have life skills, therefore they are able to be independent, have jobs, creative and have income that fullfill their daily needs.
\end{abstract}

\section{PENDAHULUAN}

Menurut Undang-Undang Nomor 19 Tahun 2011, disabilitas yaitu orang yang memiliki keterbatasan fisik, mental, intelektual, atau sensorik dalam jangka waktu lama yang dalam berinteraksi dengan ling- kungan dan sikap masyarakatnya dapat menemui ham- batan yang menyulitkan untuk berpartisipasi penuh dan efektif berdasarkan kesamaan hak (Triono, 2018). Ter- dapat beberapa istilah untuk menyebut orang-orang dengan disabilitas yang penamaannya disesuaikan dengan keterbatasan yang dimiliki seperti tunanetra (keterbatasan penglihatan), tunarungu (keterbaatasan pendengaran), tunadaksa (gangguan motorik), dan tun- alaras (tunasosial) (Nisa et al., 2018). Selain, itu ada juga kategori disabilitas dengan keterbatasan intelegen- si yang disebut tunagrahita. Tunagrahita adalah istilah yang diberikan kepada individu yang memiliki kondisi kecerdasan di bawah rata-rata atau dapat dikatakan keterbelakangan mental. Tunagrahita mengacu pada fungsi intelektual umum secara signifikan yang berada di bawah kondisi normal bersamaan dengan keku- rangan dalam tingkah laku penyesuaian diri dan semua ini berlangsung pada masa perkembangannya (Rochyadi, 2012).

Para penyandang disabilitas seringkali mendapatkan stigma dari masyarakat dan kurang diterima oleh masyarakat dikarenakan keterbatasan yang mereka miliki (Kusumastuti, et al., 2019). Penyandang tunagrahita di Indonesia rentan terhadap diskriminasi akibat minimnya informasi penyakit, pengobatan, pendidikan, akses publik, dan peluang kerja yang sangat terbatas. Dari segi pekerjaan, kesempatan kerja bagi disabilitas termasuk masyarakat tunagrahita, masih rendah. Keterbatasan yang dimiliki oleh penyandang disabilitas seringkali menjadi salah satu hal yang dipertimbangan oleh para pemilik usaha dalam 
mempekerjakan penyandang disabilitas (A, et al., 2018). Rendahnya kesempatan kerja pada masyarakat tunagrahita berdampak bagi pemenuhan hidup seharihari, sehingga banyak masyarakat tunagrahita yang menggantungkan kondisi hidupnya terhadap bantuan konsumtif pada orang lain.

Di desa Karangpatihan, Ponorogo, kondisi tunagrahita disebabkan karena kemiskinan, yang menyebabkan masyarakat tidak dapat mengakses makanan yang bergizi dengan baik yang menyebabkan cacat pada janin dan bayi yang lahir. Kemiskinan yang dialami oleh warga Desa Karangpatihan dan kurangnya asupan gizi dari buah dan sayur bagi para ibu hamil memiliki keterkaitan dalam menjadi beberapa penyebab dari lahirnya bayi dengan kondisi tunagrahita (Dewi, 2016). Hal ini diperkuat oleh keterangan Eko Mulyadi, Kepala Desa Karangpatihan, kepada media ABC. Eko Mulyadi menjelaskan bahwa banyaknya warga Desa Karangpatihan yang menyandang kondisi tunagrahita dikarenakan kurangnya gizi para ibu hamil (Renaldi \& Zhou, 2018). Kondisi lahan yang tandus, berkapur, dan kurang mengandung yodium membuat warga kesulitan dalam bercocok tanam (Susilawati, 2016). Selain itu, kejadian kegagalan panen besar-besaran di tahun 1960 yang diperparah dengan kemiskinan akibat gejolak sosial dan politik di tahun 1960-an membuat warga menggantungkan gizi sehari-hari dari umbi-umbian (Renaldi \& Zhou, 2018). Letak geografis Desa Karangpatihan yang jauh dari pusat kota juga turut menyulitkan akses warga dalam menyuplai makanan yang bergizi bagi para ibu hamil (Wulandari, et al., 2019).

Jumlah penduduk yang ada di Desa Karangpatihan adalah sebanyak 5.746 jiwa atau 1.754 kepala keluarga (KK), yang terdiri dari 2.924 laki-laki dan 2.826 perempuan. Dari jumlah KK tersebut masyarakat desa hidup dengan kondisi yang beragam, antara lain di Desa Karangpatihan terdapat 261 KK warga yang tergolong berada dalam garis kemiskinan, sedangkan kondisi masyarakat desa yang berada pada garis rentan miskin mencapai 558 KK. Selain itu Desa Karangpatihan juga terkenal dengan masyarakat tunagrahita, hal ini selaras dengan data desa yang menunjukkan bahwa terdapat $42 \mathrm{KK}$ warga yang mengalami tunagrahita. Selebihnya adalah 893 KK rata-rata dan 86 jiwa warganya mengalami keterbelakangan mental.

Banyaknya jumlah warga desa Karangpatihan yang mengalami kondisi tunagrahita mendorong Pemerintah Desa Karangpatihan dan penduduk sekitar untuk melakukan pemberdayaan masyarakat (Andriana, 2017). Mereka menyadari bahwa para warga dengan kondisi tunagrahita tidak dapat selamanya dibantu dan harus mandiri dalam memenuhi kebutuhan sehari-hari (Taqwarahmah, et al., 2017). Melalui metode pendampingan, Pemerintah Desa Karangpatihan dan penduduk desa sekitar yang terdiri dari tokoh masyarakat dan karangtaruna bekerja sama dalam proses pelaksanaan program pemberdayaan masyarakat bagi para warga desa yang menyandang kondisi tunagrahita (Aprianto, et.al., 2019).

Kajian ini bertujuan untuk menganalisis program pemberdayaan masyarakat yang dilakukan oleh Pemerintah Desa Karangpatihan melalui Kelompok Swadaya Masyarakat (KSM) Rumah Harapan Karangpatihan Bangkit yang melibatkan tunagrahita sebagai subjek pemberdayaan masyarakat.

\section{KAJIAN PUSTAKA}

Metodologi

Paradigma penelitian ini menggunakan paradigma kualitatif. Menurut Creswell (2009:33) penyelidikan kualitatif adalah sebuah cara penyelidikan dengan cara memahami makna individu atau kumpulan dalam masalah sosial atau masalah manusia.

Data penelitian dikumpulkan melalui dua cara, pertama adalah dengan wawancara mendalam dengan Kepala Desa Karangpatihan (R1), ketua pengurus Rumah Harapan "Karangpatihan Bangkit" (R2), tokoh masyarakat setempat (R3), dan penyandang tunagrahita penerima manfaat program pemberdayaan masyarakat (R4 dan R5). Data sekunder diperoleh dari Laporan Program Pemberdayaan Masyarakat Desa Karangpatihan, berita-berita mengenai program pemberdayaan Desa Karangpatihan dari media on-line. Data yang diperoleh dianalisis dengan model analisis interaktif. Model ini terdiri dari tiga komponen analisis yaitu: reduksi data, sajian data, dan penarikan kesimpulan (Miles dan Huberman, 2014). Reduksi data diartikan 
sebagai proses pemilihan, pemusatan perhatian pada penyederhanaan, pengabstrakan, dan transformasi data kasar yang muncul dari catatan-catatan tertulis di lapangan. Miles \& Huberman (2014) membatasi suatu penyajian sebagai sekumpulan informasi tersusun yang memberi kemungkinan adanya penarikan kesimpulan dan pengambilan tindakan. Penarikan kesimpulan menurut Miles \& Huberman hanyalah sebagian dari satu kegiatan dari konfigurasi yang utuh. Kesimpulankesimpulan juga diverifikasi selama penelitian berlangsung.

Adapun lokasi penelitian ini adalah di Desa Karangpatihan merupakan desa yang terletak di Kecamatan Balong, Kabupaten Ponorogo. Penelitian dilaksanakan pada bulan Februari-Juli 2019.

\section{Kajian Konseptual}

Pemberdayaan masyarakat adalah kegiatan pengembangan masyarakat yang diselenggarakan secara sistematis, terencana, dan diarahkan untuk memperbesar akses masyarakat guna mencapai kondisi sosial, ekonomi, dan kualitas kehidupan yang lebih baik (Budimanta, 2003:28). Payne (1995; 165) menambahkan pemberdayaan masyarakat merupakan usaha bersama yang terencana untuk meningkatkan kualitas kehidupan yang lebih baik dalam sektor pendidikan, kesehatan, dan sosial budaya. Pemberdayaan masyarakat memiliki fokus untuk menolong anggota masyarakat yang memiliki minat untuk bekerja sama, mengidentifikasi kegiatan bersama dan melakukan kegiatan bersama untuk memenuhi kebutuhan bersama.

Pemberdayaan masyarakat merupakan kegiatan sosial yang tujuan utamanya untuk memper- baiki kualitas hidup masyarakat melalui pemberdayaan yang ada pada mereka sehingga menekankan pada prin- sip partisipasi sosial (Suharto, 2005). Pelaksanaan pemberdayaan masyarakat dilakukan dengan siklus pengembangan komunitas yang dimulai dengan prinsip development, yaitu pengembangan konsep, tujuan, dan sasaran program berdasar community need analysis atau analisa kebutuhan komunitas (Rahman, 2009:34). Dalam melakukan analisis kebutuhan, pemberdayaan masyarakat harus memahami apa yang menjadi keinginan dan kebutuhan masyarakat. Kebutuhan tersebut sifatnya jangka panjang dan bukan sementara. Analisis kebutuhan dilakukan dengan cermat, melibatkan tokohtokoh masyarakat untuk menggali ide program yang menjadi kebutuhan bersama dan bukan kebutuhan beberapa orang saja.

Tahap selanjutnya adalah sosialisasi program sehingga sebagai sasaran kegiatan serta komunitas merasa memiliki dan bertanggung jawab terhadap pelaksanaan serta keberhasilan program. Dalam proses sosialisasi tersebut harus dilakukan melalui media dengan pesan komunikasi yang tepat. Kegiatan pemberdayaan masyarakat mengandung usaha untuk meningkatkan partisipasi dan rasa memiliki terhadap program pemberdayaan yang dilaksanakan. Partisipasi masyarakat diungkapkan oleh Ife (2009: 294) merupakan sebuah konsep utama dan prinsip dasar dari pemberdayaan masyarakat. Partisipasi masyarakat merupakan salah satu bentuk pemberdayaan masyarakat yang berorientasi pada pencapaian hasil pelaksanaan yang dilakukan masyarakat.

Menurut Zubaedi (2007:77) terdapat tiga cara yang dilakukan agent of change sebelum melakukan kegiatan pemberdayaan masyarakat yakni isu, masalah, dan kebutuhan masyarakat. Setelah menganalisis kebutuhan masyarakat ditentukan, diperlukan agent of change dalam melakukan kegiatan pemberdayaan masyarakat dalam melaksanakan program pembangunan diperlukan partisipasi masyarakat karena dalam proses akhir masyarakat yang akan menikmati hasil dari pembangunan tersebut dan masyarakat tidak hanya menjadi subjek namun juga menjadi objek dalam pembangunan. Kegiatan pengembangan masyarakat bukan hanya digunakan untuk membangun kehidupan material, melainkan juga dalam bidang nonmaterial. Nasution (2012:89) memberikan pemahaman terhadap konsep yang menjembatani aspek nonmaterial dari pembangunan dengan memandang kegiatan ini sebagai suatu proses perolehan pengetahuan, informasi, dan keterampilan-keterampilan baru selain merupakan alat, keterampilan juga sebagai hasil proses pembangunan bagi mereka yang menjalaninya.

Dalam proses pelaksanaan pemberdayaan masyarakat, ada beberapa hal yang harus diperhatikan oleh para pihak yang terlibat (Maani, 2011). Pertama, pemberdayaan masyarakat harus mampu menciptakan 
suasana atau iklim yang memungkinkan masyarakat berkembang. Kedua, membantu masyarakat dalam proses pemberdayaan masyarakat dengan cara memberikan bantuan dana, pelatihan, pengembangan kelembagaan di wilayah masyarakat setempat, dan membantu pembangunan sarana dan prasarana baik secara fisik maupun sosial. Hal yang perlu diperhatikan terakhir adalah memberikan perlindungan dan memihak masyarakat yang lemah dalam mencegah terjadinya persaingan yang tidak seimbang dan menciptakan hubungan saling menguntungkan antar para mitra. Jika tiga hal tersebut diperhatikan dengan baik dalam pelaksanaan pemberdayaan masyarakat maka program pemberdayaan masyarakat dapat berhasil dalam meningkatkan kesejahteraan rakyat.

Pemberdayaan masyarakat adalah konsep pembangunan ekonomi yang merangkum nilai-nilai sosial. Peningkatan yang dituju tidak hanya ekonominya, tetapi juga harkat, martabat, rasa percaya diri dan harga dirinya. Dasar pemikiran pemberdayaan masyarakat adalah bahwa upaya yang dilakukan harus diarahkan langsung pada akar persoalannya, yaitu meningkatkan kemampuan rakyat. Konsep ini mencerminkan paradigma baru pembangunan, yakni bersifat: "people-centered, participatory, empowering, and sustainable (Chambers, 1995). Paradigma yang dibawa oleh Chambers menandakan pentingnya pembangunan yang berpusat pada manusia, bersifat partisipatif, memberdayakan, dan berkelanjutkan. Konsep pemberdayaan masyarakat tidak mempertentangkan pertumbuhan dengan pemerataan, tetapi justru sebaliknya mencoba memadukan pertumbuhan dan pemerataan.

Pemberdayaan masyarakat menurut Suharto dalam buku Manajemen Pemberdayaan Masyarakat karya Hamid (2018:11) bertujuan untuk meningkatkan kekuatan atau kemampuan orang khususnya kelompok rentan dan lemah dalam menghadapi berbagai kondisi. Pertama, masyarakat memiliki kekuatan atau kemampuan dalam memenuhi kebutuhan dasarnya berupa kebebasan dari rasa kelaparan, kebebasan dalam mengungkapkan pendapat, bebas dari kebodohan, dan bebas dari rasa kesakitan. Kedua, masyarakat memiliki kekuatan atau kemampuan dalam menjangkau sumber- sumber produktif agar mereka dapat meningkatkan pendapatanya dan mampu memperoleh barang dan jasa yang dibutuhkan. Ketiga, masyarakat memiliki kekuatan atau kemampuan dalam berpartisipasi di setiap proses pembangunan dan pengambilan keputusan yang mempengaruhi kehidupan mereka.

\section{TEMUAN DAN DISKUSI}

Berdasarkan latar belakang mengenai kondisi warga Desa Karangpatihan yang banyak meyandang kondisi tunagrahita dan adanya inisiasi Pemerintah Desa Karangpatihan untuk melakukan pemberdayaan masyarakat guna memperbaiki taraf hidup warga Desa Karangpatihan, maka hasil penelitian dan pembahasan mengenai program pemberdayaan masyarakat yang dilakukan oleh Pemerintah Desa Karangpatihan melalui Kelompok Swadaya Masyarakat (KSM) Rumah Harapan Karangpatihan Bangkit adalah sebagai berikut.

\section{Peran KSM Rumah Harapan dalam Pemberdayaan Tunagrahita di Karangpatihan Bangkit}

Program pemberdayaan masyarakat Kelompok Swadaya Masyarakat (KSM) Rumah Harapan Karangpatihan Bangkit merupakan sebuah program yang dibentuk oleh Pemerintah Desa Karangpatihan untuk memudahkan dalam proses kegiatan pemberdayaan sehingga dapat mendorong peningkatan taraf ekonomi masyarakat tunagrahita di Desa Karangpatihan. Hal tersebut diawali dengan adanya inisiatif warga untuk membuat tempat dan membentuk pengurus untuk pemberdayaan masyarakat tunagrahita. Setelah diadakan musyawarah dan sosialisasi dengan warga dan juga sebagian perangkat desa maka terbentuklah beberapa orang yang mewakili sebagai Pengurus Rumah Harapan.

"Dulu kegiatan pemberian ketrampilan kepada tunagrahita masih berjalan seadanya, kadang di rumah saya, kadang di tempat pak Eko. Karena kegiatan yang dilakukan kurang maksimal, akhirnya kami mem- bentuk beberapa orang yang ditunjuk untuk mengu- rusnya dan membangun tempat sebagai wadahnya" (Wawancara dengan Ketua Pengurus Rumah Harapan) 
Menurut Bapak Eko Mulyadi, selaku Kepala Desa Karangpatihan sekaligus salah satu penggagas program pemberdayaan masyarakat, KSM Rumah Harapan Karangpatihan Bangkit dibentuk sebagai upaya untuk mendidik, membina, dan melatih masyarakat tunagrahita guna mendapatkan keterampilan sehingga bisa melakukan kegiatan ekonomi secara mandiri tanpa bantuan orang lain. Sebagaimana kutipan wawancara dengan beliau sebagai berikut:

"Rumah harapan adalah tempat pelatihan untuk masyarakat tunagrahita, jadi bertujuan mendidik, membina, dan melatih warga tunagrahita agar mendapatkan keterampilan sehingga mereka dapat memiliki pendapatan guna memenuhi kebutuhan hidup keseharian mereka” (Kepala Desa Karangpatihan)

Sejalan dengan pandagan Kepala Karangpatihan Bangkit, salah seorang pengurus KSM Rumah Harapan menambahkan pernyataan berikut:

"Secara umum warga miskin tunagrahita dilatih dan didampingi di Rumah Harapan, jadi mereka dilatih untuk membuat kerajinan tangan, budidaya lele semuanya di sini. Setelah dibentuk pengurus dalam rumah harapan itu, jadi mereka bergeraksecara sukarela untuk masyarakat tunagrahita” (Pengurus Rumah Harapan)

Program pemberdayaan masyarakat Rumah Harapan Karangpatihan Bangkit merupakan sebuah upaya pemberdayaan ekonomi masyarakat tunagrahita yang bekerjasama dengan masyarakat sebagai pendamping dan pengurus, serta mendatangkan pendamping dari luar untuk memberikan pelatihan dan pendampingan. Pendampingan yang dilakukan di Rumah Harapan Karangpatihan Bangkit tidak menggunakan biaya atau modal yang besar, karena pendamping tersebut melakukannya secara sukarela dan tidak mengharapkan biaya atau upah dalam proses pendampingan dan pelatihan kepada masyarakat tunagrahita.

\section{Pengurus Rumah Harapan di Desa} Karangpatihan bekerja secara sukarela untuk melatih dan memberdayakan masyarakat tunagrahita. Mereka bahkan selalu mendampingi setiap kegiatan yang dilakukan oleh masyarakat tunagrahita. Adapun tahaptahap dalam pemberdayaan masyarakat di Desa Karangpatihan adalah: (1) identifikasi masalah. Proses ini adalah proses paling awal yang dilakukan dalam pengembangan masyarakat dimana pemerintah mengelompokkan dan menentukan persoalan yang dihadapi oleh masyarakat.

Pada awal tahun 2013 Pemerintah Desa Karangpatihan terdorong untuk melakukan kegiatan pemberdayaan masyarakat untuk memberdayakan masyarakat Desa Karangpatihan yang mengalami keterbelakangan mental menjadi lebih berdaya, karena pada saat itu masyarakat tunagrahita di Desa Karangpatihan belum mandiri dan bergantung kepada bantuan konsumtif yang diberikan oleh masyarakat lain tentunya. Hal ini membutuhkan adanya sikap kepedulian oleh masyarakat yang berada di Desa Karangpatihan.

Warga tunagrahita yang diberdayakan oleh masyarakat adalah tunagrahita ringan dan masih bisa melakukan aktivitas serta dapat berinteraksi sebagaimana manusia normal lainnya, sedangkan warga tunagrahita dalam kondisi berat tidak bisa untuk diberdayakan. Masyarakat tunagrahita di Desa Karangpatihan awalnya terkendala modal untuk melakukan kegiatan usaha. Dengan adanya permasalahan tersebut dan untuk mencapai tujuan ekonomi masyarakat tunagrahita yang lebih baik maka Pemerintah Desa Karangpatihan membentuk sebuah program pemberdayaan masyarakat melalui program KSM Rumah Harapan Karangpatihan Bangkit.

Kedua, adalah tahap analisis masalah. Tahapan analisis masalah ini dilakukan oleh Pemerintah Desa Karangpatihan bersama masyarakat lokal mencari jalan keluar dari permasalahan yang dialami oleh masyarakat tunagrahita. Masalah yang dihadapi antara lain kurangnya modal dalam pembuatan program, belum ada pendamping yang melakukan pelatihan terhadap masyarakat tunagrahita dan kurangnya sarana dan prasarana dalam pembuatan program.

Melalui pelibatan masyarakat setempat, kesadaran masyarakat yang mulai timbul, kepedulian terhadap program pemberdayaan masyarakat yang meningkat. Pembentukan pendamping Rumah Harapan 
Karangpatihan Bangkit dijadikan kebutuhan yang harus segera dibentuk dalam kegiatan pemberdayaan. Sehingga dengan adanya bantuan dari Kepala Desa Karangpatihan dibentuklah pengurus KSM Rumah Harapan Karangpatihan Bangkit.

Ketiga, tahap tindakan. Tahap ini terkait metode dan strategi yang tepat terkait program pemberdayaan masyarakat yang dilakukan oleh Pemerintah Desa Karangpatihan adalah melalui proses pendampingan kepada tunagrahita. Pada awalnya pengurus mendatangi rumah masyarakat tunagrahita untuk membujuk mereka mengikuti kegiatan pelatihan ketrampilan yang dilakukan di Rumah Harapan. Lambat laun, para tunagrahita tertarik untuk mengikuti kegiatan-kegiatan yang difasilitasi oleh Rumah Harapan.

Tahap terakhir adalah evaluasi. Evaluasi yang dilakukan adalah dengan melihat indikator keberhasilan yang ditetapkan serta survey yang dilakukan pengurus Rumah Harapan Karangpatihan Bangkit terkait program pemberdayaan masyarakat dan evaluasi program yang dijalankan Hasil dari program pemberdayaan masyarakat yaitu warga tunagrahita dapat memiliki pendapatan. Setelah diadakan pelatihan yang dilakukan di Rumah Harapan para tunagrahita mendapatkan penghasilan harian, triwulan, dan juga tahunan. Berikut adalah petikan wawancara:

"Produksi kerajinan dan peternakan mampu menghasilkan pendapatan, harian, triwulan, dan ta- hunan. Pendapatan harian diperoleh dari kerajinan keset yang sudah berjalan lama dan mereka ini dapat memproduksi keset sekitar satu sampai lima buah dalam waktu sehari. Pendapatan dari peternakan lele adalah untuk triwulan dan untuk penghasilan tahunan kami ada peternakan kambing yang dilakukan secara bergiliran." (Ketua pengurus Rumah Harapan Karangpatihan Bangkit)

Dapat dikatakan program pemberdayaan ini cukup berhasil. Program ini mampu memecahkan masalah dan mengubah tentang predikat dari kampung tunagrahita ini menjadi Kampung Mandiri dan warga tunagrahita di desa Karangpatihan ini mampu melaksanakan program pemberdayaan masyarakat.

\section{Peran Pendamping Tuna Grahita Dalam Mem- bangun Kemandirian Ekonomi Dan Sosial}

Tahapan pelaksanaan program yang dilakukan oleh Pemerintah Desa Karangpatihan disesuaikan dengan perencanaan yang sebelumnya disepakati bersama masyarakat Desa Karangpatihan yaitu kegiatan pelatihan, penyebaran informasi, dan penyadaran masyarakat. Tahapan pelaksanaan program diawali dari pelatihan. Pelatihan yang dilakukan adalah pelatihan kerajinan, pemilahan, pelatihan budidaya lele, peternakan, pelatihan pemasaran, dan pelatihan lainnya yang berhubungan terkait program KSM Rumah Harapan Karangpatihan Bangkit. Dalam pelatihan membuat kerajinan berfokus pada pelatihan yang dilakukan dengan mengajarkan bagaimana cara membuat kerajinan, mengajari satu per satu masyarakat tunagrahita. Pelatihan itu sendiri diadakan mulai tahun 2013 bertempat di Rumah Harapan Karangpatihan Bangkit. Pelatihan yang dilakukan oleh Pemerintah Desa Karangpatihan maupun pengurus dilakukan dengan praktik yang sederhana melalui penyuluhan secara kelompok dan berkomunikasi melalui bahasa isyarat. Pendampingan tersebut tepat untuk dilakukan sebagai kegiatan pemberdayaan masyarakat tunagrahita, karena masyarakat tunagrahita juga memiliki pola interaksi yang sama dengan manusia normal lainnya.

Proses pendampingan oleh pengurus Rumah Harapan Karangpatihan Bangkit dilakukan pada setiap kegiatan atau pelatihan usaha dengan mengarahkan mereka hingga masyarakat yang dilatih mampu melakukannya secara mandiri. Pengurus dan pendamping tidak mendapatkan upah namun mereka membantu masyarakat tunagrahita secara sukarela.

Pendamping mengajarkan para tunagrahita melalui praktik yang sederhana dan menyesuaikan kondisi masyarakat tunagrahita yang diberdayakan. Program pelatihan yang diberikan antara lain adalah Pembudidayaan Ternak Ikan Lele. Kegiatan usaha pertama kali yang dilakukan oleh Pemerintah Desa Karangpatihan yaitu dengan budidaya lele. Warga tunagrahita dibuatkan kolam dengan ukuran $1 \times 2$ meter. Lalu mereka didampingi untuk dibantu bagaimana cara memberi pakan, memanen, dan menguras. Warga 
tungrahita di Desa Karangpatihan tidak bisa melakukan baca tulis sehingga waktu untuk memberi makan ikan lele ditentukan dari arah sinar matahari. Pelatihan budidaya lele ini cukup mudah dilakukan oleh warga tunagrahita. Sebagaimana hasil wawancara dengan informan:

Dalam melatih warga tunagrahita pengurus KSM Rumah Harapan Karangpatihan Bangkit harus sabar dalam memberikan pelatihan terhadap warga tunagrahita supaya mereka tertarik dalam kegiatan budidaya ikan lele ini. Sebagaimana hasil wawancara dengan informan:

"Pelatihan budidaya lele ini sangat memerlukan kesabaran, karena harus menggunakan bahasa isyarat untuk proses komunikasinya, karena warga tunagrahita ini harus dilatih secara insentif supaya mereka bisa melakukannya, namun dengan adanya kesabaran yang dilakukan, pada akhirnya warga tunagrahita mampu secara mandiri dalam kegiatan budidaya ikan lele ini" (Pengurus Rumah Harapan Karangpatihan Bangkit)

Selanjutnya menurut keterangan Bapak Samuji, Ketua pengurus Rumah Harapan Karangpatihan Bangkit, hasil dari budidaya ikan lele ini cukup lumayan untuk memenuhi kebutuhan sehari-hari warga tunagrahita.

"Kami dari pengurus memberdayakan masyarakat tunagrahita dengan dibekali kemampuan untuk budidaya ikan lele supaya mereka dapat bekerja secara mandiri, hasil penjualan ikan lele ini juga sangat lumayan digunakan dalam pemenuhan kebutuhan hidup sehari- hari yaitu mereka mendapatkan hasil antara Rp 100 ribu hingga $R p 300$ ribu setiap bulannya. Pengurus juga mengajak masyakat setempat untuk membeli ikan lele hasil produksi warga tunagrahita ini supaya mereka dapat berkembang untuk kegiatan selanjutnya." (Samuji,wawancara, 2019)

Dari kegiatan budidaya ikan lele ini warga tunagrahita dapat menjalankannya dengan baik yang dilakukan oleh Pemerintah Desa Karangpatihan dan pengurus KSM Rumah Harapan Karangpatihan Bangkit. Dimana pengurus memberikan pelatihan menggunakan bahasa isyarat. Meskipun cukup sulit dilakukan namun warga tunagrahita bersemangat dalam melakukan kegiatan budidaya ikan lele tersebut.

Selanjutnya tunagrahita juga dilatih pembuatan kerajinan tangan tasbih, keset, dan batik. Tasbih merupakan salah satu kerajinan yang dibuat dari manik -manik yang dirangkai dengan menggunakan benang. Menurut Bapak Samuji, untuk membuat satu kerajinan tasbih warga tunagrahita harus mampu menghitung manik-manik yang berjumlah 33. Pembuatan kerajinan tasbih ini sangat ditentukan oleh adanya tingkat ketelitian yang dilakukan warga tunagrahita, karena mereka terkadang salah dalam proses penghitungannya, karena banyak warga tunagrahita yang tidak bisa berhitung.

"Kerajinan tasbih ini diperlukan kemampuan menghitung dan proses pelatihan yang cukup sulit karena warga tunagrahita harus selalu didampingi dalam kegiatan pembuatan tasbih ini, karena terkadang mereka salah menghitung, sudah sampai 27 saja mereka rangkai kalau tidak ditunggu." (Pengurus Rumah Harapan Karangpatihan Bangkit)

Keset merupakan salah satu kerajinan yang bisa digunakan dan dimanfaatkan dalam kehidupan rumah tangga, dengan bermodalkan sisa-sisa kain perca dapat digunakan sebagai kerajinan keset. Rumah Harapan melatih masyarakat tunagrahita dengan membuat kerajinan keset yang bermodalkan dana dari donasi, maupun dari hasil penjualan keset tersebut.

Gambar 1.1 Masyarakat tunagrahita yang sedang membuat kerajinan keset

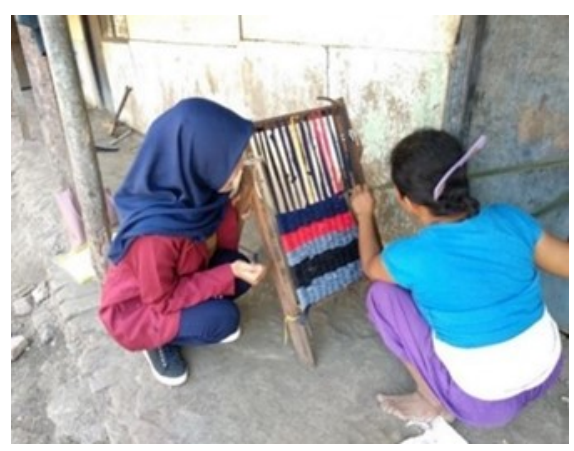


Pembuatan keset ini bisa dikerjakan di rumah harapan dan juga dibawa ke rumah mereka masingmasing. Berikut kutipan wawancaranya:

“Ketika ada kegiatan kunjungan atau kumpulan ya mereka membuat kerajinan keset ini di Rumah Harapan, tapi supaya lebih maksimal dan mandiri, mereka membawa kerajinan keset ini untuk dikerjakan di rumah mbak, tapi tergantung kalau mereka sudah benar-benar bisa ya mereka bawa alat untuk dikerjakan di rumah. Karena kadang masyarakat tunagrahita itu kalau dikumpulkan di sini dan disuruh buat keset mereka ada yang sama sekali tidak mau dan masih membutuhkan pendampingan” (Bapak Samuji, selaku ketua pengurus Rumah Harapan Karangpatihan Bangkit, hasil wawancara 3 Juli 2019).

Gambar 1.2 Proses Pelatihan Pembuatan Keset oleh Masyarakat Tunagrahita

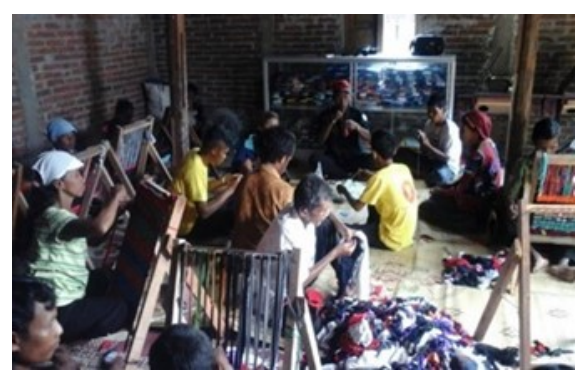

Sumber: Dokumentasi Pengurus Rumah Harapan

Dengan pelatihan dan proses yang sederhana mereka dikumpulkan dan dilatih oleh pengurus satu per satu, kemudian juga diberi pemahaman yang berkaitan dengan proses pemilihan warna, pemasangan alat, perangkaian, hingga pengancingan pada proses akhir.

Bahkan hasil kerajinan keset yang dibuat oleh warga tunagrahita hasilnya lebih bagus dan rapi daripada masyarakat normal. Adapun Batik Ciprat merupakan batik yang unik dimana dibuat oleh penyandang disabilitas dengan cara diciprat-cipratkan larutan malam pada sebuah kain secara acak. Batik ciprat masyarakat tunagrahita di Desa Karangpatihan ini hasilnya akan berbeda antara satu kain dengan kain yang lainnya. Sebab diproduksi secara manual bukan menggunakan mesin. hasilnya akan berbeda antara satu kain dengan kain yang lainnya. Sebab diproduksi secara manual bukan menggunakan mesin.

Gambar 1.3 Proses Pembuatan Batik Ciprat oleh Masyarakat Tunagrahita

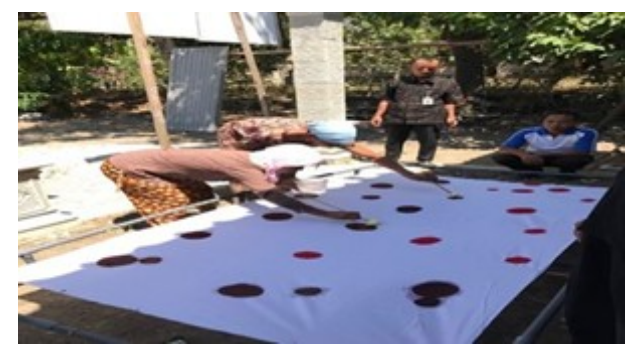

Sumber: Dokumentasi Pengurus Rumah Harapan

“Batik ciprat ini merupakan kegiatan pemberdayaan yang dilakukan kepada masyarakat tunagrahita dan diharapkan warga akan mampu memproduksi batik sendiri sehingga akan menambah penghasilan bagi warga masyarakat tunagrahita”. (Eko Mulyadi, Kepala Desa Karangpatihan, hasil wawancara 3 Juli 2019)

Tidak hanya batik ciprat di Desa Karangpatihan juga membuat batik canting tergantung pesanan pembeli. Batik Ciprat di Desa Karangpatihan ini juga banyak diminati para pejabat di Kabupaten Ponorogo maupun di luar daerah.

"Pembuatan batik ini juga kadang menggunakan cara sederhana mbak, pakai daun untuk membentuk polanya, jadi unik dan banyak diminati pembeli" (Samuji, Ketua Pengurus Rumah Harapan Karangpatihan Bangkit, hasil wawancara 3 Juli 2019)

Untuk batik ciprat karya masyarakat tunagrahita ini dipasarkan dengan harga Rp 150.000. Pembuatan batik ciprat oleh masyarakat tunagrahita di Desa Karangpatihan ini bertujuan untuk meningkatkan kreativitas dan perekonomian masyarakat tunagrahita di Desa Karangpatihan.

\section{Analisis}

Program pemberdayaan masyarakat yang dilakukan Pemerintah Desa Karangpatihan meliputi kegiatan pelatihan dan pendampingan kepada warga tunagrahita di desa tersebut sebanyak 80 orang. Melalui proses pendampingan sebagai strategi pemberdayaan masyarakat, maka masyarakat Tunagrahita Desa 
Karangpatihan dapat dilibatkan secara intens dalam kegiatan dan program yang dilaksanakan. Tujuan program pemberdayaan masyarakat Pemerintah Desa Karangpatihan adalah mengubah masyarakat yang tidak berdaya menjadi berdaya, dan tidak bergantung pada masyarakat lain, dalam prosesnya perlu diperhatikan strategi-strategi yang tepat. Hal ini sesuai dengan Budimanta (2003) yang mengatakan strategi pemberdayaan masyarakat adalah kegiatan peningkatan taraf hidup masyarakat yang dilakukan dengan terstruktur, terprogram, dan ditujukan untuk memperluas jaringan komunitas lokal dalam rangka menggapai kondisi sosial, ekonomi, dan kualitas kehidupan yang lebih baik. Pemberdayaan masyarakat yang dilakukan di Dusun Karangpatihan melalui proses komunikasi vertikal dan horizontal yang bertujuan melalui proses ini diharapkan masyarakat tidak hanya sebagai objek pembangunan, akan tetapi dapat ikut berperan aktif dalam pelaksanaannya.

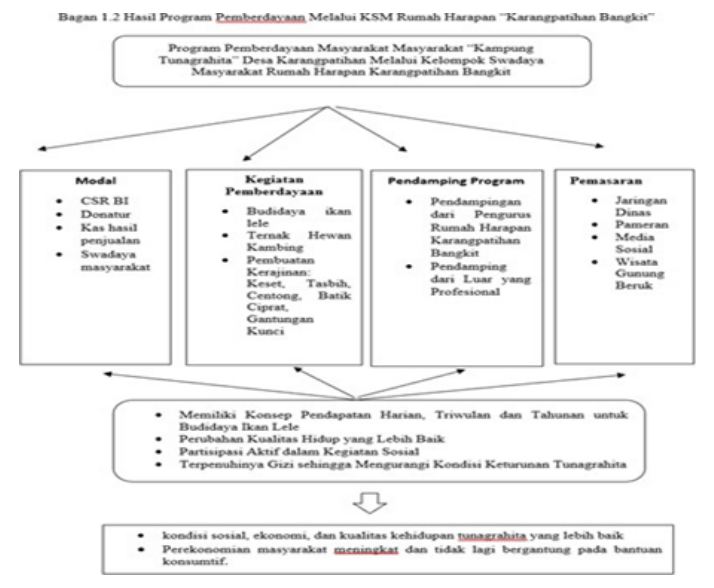

Media adalah sarana yang mendukung dalam proses kegiatan komunikasi agar pesan yang disampaikan komunikator dapat sampai dengan baik kepada komunikan. Berbagai media digunakan untuk menyampaikan pesan yang dilakukan dalam menyampaikan pesan dalam program pemberdayaan masyarakat antara lain melalui komunikasi interpersonal dan komunikasi kelompok. Komunikasi interpersonal dan kelompok dinilai lebih efektif karena yang menjadi komunikan merupakan warga tunagrahita sehingga melalui media tatap muka dengan menggunakan bahasa isyarat, warga tunagrahita pun bisa mendapat informasi dan feedback secara langsung mengenai program pemberdayaan masyarakat.
Melalui program pemberdayaan masyarakat, terjadi peningkatan kondisi sosial, ekonomi, dan kualitas kehidupan tunagrahita yang lebih baik. Pelatihan yang dilakukan oleh Pemerintah Desa Karangpatihan maupun pengurus dilakukan dengan praktik yang sederhana melalui penyuluhan secara kelompok dan berkomunikasi melalui bahasa isyarat. Pelatihan tersebut tepat untuk dilakukan sebagai kegiatan pemberdayaan masyarakat tunagrahita, karena masyarakat tunagrahita juga memiliki pola interaksi yang sama dengan manusia normal lainnya.

Hal ini juga sejalan dengan Ife (2009: 178), bahwa proses kegiatan berkelompok, membangun rasa saling percaya diri, dan membangun semangat bersama sangat diperlukan untuk mencapai tujuan dalam membangun masyarakat. Proses dan hasil (process and outcome) pun menjadi hal yang sangat penting dalam kegiatan pemberdayaan, sehingga dapat menambah wawasan dan motivasi yang menyeluruh terhadap masyarakat tunagrahita.

Proses pendampingan oleh pengurus Rumah Harapan Karangpatihan Bangkit dilakukan pada setiap kegiatan atau pelatihan usaha dengan mengarahkan mereka hingga masyarakat yamg dilatih mampu melakukannya secara mandiri. Pengurus dan pendamping tidak mendapatkan upah namun mereka membantu masyarakat tunagrahita secara sukarela. Peneliti melihat bahwa pendampingan yang dilakukan oleh pengurus Rumah Harapan Karangpatihan Bangkit dilaksanakan sebagai proses kegiatan pemberdayaan masyarakat, karena dengan adanya proses pendampingan maka warga tunarahita akan lebih mudah untuk melakukan proses kegiatan pemberdayaan masyarakat yang telah diberikan pelatihan oleh pengurus Rumah Harapan Karangpatihan Bangkit. Melalui program pemberdayaan masyarakat tunagrahita tidak lagi menjadi beban masyarakat tapi mampu menjadi warga yang mandiri sehingga stigma "kampong tunagrahita" telah berubah menjadi kampung mandiri. Hal ini juga sesuai dengan Chambers (1995) bahwa pemberdayaan masyarakat adalah konsep pembangunan ekonomi yang merangkum nilai-nilai sosial. Peningkatan yang dituju tidak hanya ekonominya, 
tetapi juga harkat, martabat, rasa percaya diri, dan harga dirinya.

\section{KESIMPULAN}

Pemberdayaan masyarakat adalah kegiatan peningkatan taraf hidup masyarakat yang dilakukan dengan terstruktur, terprogram, dan ditujukan untuk memperluas jaringan komunitas lokal dalam rangka menggapai kondisi sosial, ekonomi, dan kualitas kehidupan yang lebih baik. Pemberdayaan masyarakat yang dilakukan di Dusun Karangpatihan bertujuan untuk meningkatkan kualitas kehidupan penyandang tunagrahita di Dusun Karangpatihan, Kabupaten Ponorogo. Pemberdayaan masyarakat dilakukan dalam tiga tahapan yakni identifikasi masalah, pelaksanaan, dan evaluasi. Dalam tahap identifikasi masalah, Pemerintah Desa Karangpatihan dan warga setempat mencari jalan keluar dari berbagai permasalahan yang dialami oleh masyarakat tunagrahita. Dalam tahap pelaksanaan, permasalahan yang telah dipetakan mulai diselesaikan oleh Pemerintah Desa Karangpatihan dengan melibatkan warga setempat dan para pendamping melalui program pemberdayaan masyarakat. Dalam pelaksanaan program, pemberdayaan masyarakat dilakukan dengan proses komunikasi vertikal dan horizontal yang bertujuan melalui proses ini diharapkan masyarakat tidak hanya sebagai objek pembangunan, akan tetapi dapat ikut berperan aktif dalam pelaksanaannya. Komunikasi interpersonal dan kelompok dinilai lebih efektif karena yang menjadi komunikan merupakan warga tunagrahita sehingga melalui media tatap muka dengan menggunakan bahasa isyarat, warga tunagrahita pun bisa mendapat informasi dan feedback secara langsung mengenai program pemberdayaan masyarakat. Dalam tahap evaluasi, kesuksesan program pemberdayaan masyarakat diukur melalui indikator keberhasilan serta survey yang dilakukan pengurus Rumah Harapan Karangpatihan Bangkit. Program pemberdayaan masyarakat dilakukan melalui pendampingan terhadap warga tunagrahita melalui penyuluhan secara individu dan kelompok dengan menggunakan bahasa isyarat. Melalui pendampingan yang efektif, tunagrahita di Desa Karangpatihan memiliki life skill, dan keterampi- lan sehingga mampu mandiri, memiliki pekerjaan dan kreatif serta memiliki pendapatan yang dapat membantu keperluan diri mereka sehari-hari.

\section{DAFTAR PUSTAKA}

A, G. P., Apsari, N. C., \& Mulyana, N. (2018). Penyandang Disabilitas Dalam Dunia Kerja. Focus: Jurnal Pekerjaan Sosial, Vo. 1, No. 3, $234 \quad-244$

Alfitri. (2011). Community Development: Teori dan Aplikasi. Yogyakarta: Pustaka Pelajar

Andriana, L. (2017). Kesejahteraan Sosial Tunagrahi ta di Ponorogo. Inklusi: Journal of Disabillity Studies, Vol. 4, No.1, 25-48.

Aprianto, K. T., Rasyad, A., \& Zulkarnain. (2019). Pendampingan Partisipatori dalam Meningkatkan Kemandirian Masyarakat Tunagrahita. Jurnal Pendidikan: Teori, Penelitian, dan Pengembangan, Vol. 4, No. 6, 795-802.

Budimanta, A. (2003). Pengelolaan Community Development. Jakarta: Indonesian Center for Sustainable Development.

Dewi, D. S. K. (2016). Model Pemberdayaan Masyarakat Tunagrahita di Kampung Idiot Kabupaten Ponorogo. Jurnal Ilmu Pemerintahan, Vol. 6,No. 1, 21-27.

Dilla, S. (2007). Komunikasi Pembangunan. Ban dung: Simbiosa Rekatama Media.

Hamid, H. (2018). Manajemen Pemberdayaan Masyarakat. Makassar: De La Macca.

Ife, Jim. (2008). Alternatif Pengembangan Masyarakat di Era Globalisasi: Community Development. Yogyakarta: Pustaka Pelajar.

Iskandar. (2008). Metodologi Penelitian Pendidikan dan Sosial (Kuantitatif dan Kualitatif). Jakar ta: GP Press.

Kusumastuti, F., Leonardo, J., \& Widiatmojo, R. (2019). Narasi Tentang Autism di Facebook (Studi Autoetnografi pada Status K.W). Interaksi: Jurnal Ilmu Komunikasi, Vol. 8, No. 


\section{$2, \quad 57-67$.}

Maani, K.D. (2011). Teori ACTORS dalam Pem berdayaan Masyarakat. Demokrasi Vol. X, No. 1.

Mardalis, (1999). Metode Penelitian Suatu Pendekatan Proposal. Jakarta: Bumi Aksara

Miles,M.B, Huberman,A.M, dan Saldana,J. 2014. Qualitative Data Analysis, A Methods Source book, Edition 3. USA: Sage Publications. Ter jemahan Tjetjep Rohindi Rohidi, UI-Press.

Moleong, L (2014). Metode Penelitian Kualitatif. PT. Remaja Rosdakarya: Bandung.

Mulyana, D. (2010). Ilmu Komunikasi: Suatu Pengantar. Bandung: PT Remaja Rosdakarya

Muslimin. (2010). Komunikasi Pem bangunan. Malang: Jurusan Ilmu Komunikasi

Nasution. 1996. Metode Penelitian Naturalistik Kualitatif. Bandung: Tarsito

Nasution, Z. (2004). Komunikasi Pembangunan: Pengenalan Teori dan Penerapannya. Jakarta: PT Raja Grafindo Persada.

Nisa, K., Mambela, S., \& Badiah, L. I. (2018). Karakteristik dan Kebutuhan Anak Berkebutuhan Khusus. Jurnal Abadimas Adi Buana, Vol. 02 No. 1 .

Payne, M. (1995). Social Work and Community Care. London: Mc Millan

Raco, C. (2010). Metode Penelitian Kualitatif, Jenis, Karakteristik dan Keunggulannya. Jakarta: Gramedia

Rahman, R. (2009). Corporate Social Responsibility: Antara Teori dan Kenyataan. Yogyakarta: Media Pressindo

Renaldi, E. \& Zhou C. (25 Juni 2018). Transformasi di Ponorogo: Dari 'Kampung Idiot' Menjadi ' Desa Wisata'. Diakses dari https:// www.abc.net.au/ indonesian/2018-06-25/ kampung-idiot-jadi-desa-wisata/9846420

Rochyadi, E. (2012). Karakteristik Pendidikan Anak Tunagrahita. Modul Universitas Pendidikan Indonesia

Salmiah, Siti. (2010). Retardasi Mental. Medan: De partemen Ilmu Kedokteran Gigi dan AnakUni versitas Sumatera Utara
Suharto, E. (1997). Pembangunan Kebijakan Sosial dan Pekerjaan Sosial (Spektrum Pemikiran). Bandung: Lembaga Studi Pembangunan

Surakhmad, W. (1990). Penelitian Ilmiah Dasar Metode dan Teknik. Bandung: Tarsito.

Susilawati, I. (2016). Pemberdayaan Masyarakat Miskin Penyandang Disabilitas Melalui Pengembangan Industri Kreatif "Limbah Singkong" di Kabupaten Ponorogo. Jurnal Len tera: Kajian Keagamaan, Keilmuan, dan Teknologi, Vol. 14, No. 2, 224-242.

Taqwarahmah, C. G., Riyono, B., \& Setiyawati, D. (2017). Peran Karang Taruna dalam Pemberdayaan Penyandang Disabilitas di Desa Karangpatihan, Kabupaten Ponorogo dan Implikasinya Terhadap Ketahanan Ekonomi Keluarga. Jurnal Ketahanan Nasional, Vol. 23, No. 1, 37-48.

Triono, B. (2018). Kebijakan Pemberdayaan Masyara kat Difabel Idiot di Desa Karangpatihan Kecamatan Balong Kabupaten Ponorogo Jawa Timur. Jurnal Ilmu Administrasi Publik, Vol.5 No.1.

Wulandari, R., Anjasari, H., Wulandari, N. D., Jayanti, M. N., \& Gunarhadi. (2019). Pemberdayaan Warga Keterbelakangan Mental di Desa Karangpatihan Ponorogo Melalui Frutable Greden. Jurnal Pemberdayaan Masyarakat Universitas Al Azhar Indonesia, Vol. 01, No. 02 .

Zubaedi. (2007). Wacana Pembangunan Alternatif. Yogyakarta: Ar-Ruzza Media

Zubaedi. (2013). Pengembangan Masyarakat: Wacana \& Praktik. Jakarta: Kencana Prenada Media Group 